\title{
A NOTE ON THE STATUS OF GALBA OCCULTA JACKIEWICZ, 1959 (GASTROPODA: HYGROPHILA: LYMNAEIDAE)
}

\author{
JOANNA R. PIEŃKOWSKA, ANDRZEJ LESICKI*
}

\author{
Department of Cell Biology, Institute of Experimental Biology, Faculty of Biology, \\ Adam Mickiewicz University, Umultowska 89, 61-614 Poznań, Poland \\ (pienkowj@amu.edu.pl, alesicki@amu.edu.pl) \\ *corresponding author (https://orcid.org/0000-0002-1924-1934)
}

ABSTRACT: The comparison of the gene nucleotide sequences (mitochondrial cytochrome oxidase $\mathrm{c}$ subunit I and ITS2 fragment of the nuclear rDNA) indicated significant differences within the lymnaeid species of the genus Ladislavella. For this reason, we postulate retaining of the name Ladislavella occulta (Jackiewicz, 1959) for the molecularly separated lineage of the species occurring in Poland.

KEY WORDS: COI, ITS2, Ladislavella, L. occulta, L. terebra, Stagnicola, Lymnaea, taxonomy, classification

\section{INTRODUCTION}

JACKIEWICZ (1959) recognised a new species within the complex species Galba palustris (O. F. Müller, 1774) and named it G. occulta. The species was subsequently assigned to Stagnicola Jeffreys, 1830 treated as a subgenus within Lymnaea Lamarck, 1799 (JACKIEWICZ 1993, 1998a, 2000) or as a separate genus (FALKNER 1995, FALKNER et al. 2001, GLÖER 2002, GLÖER \& MEIER-BROOK 2003). When taxonomic decisions based on the analysis of nucleotide sequences took on significance, MEIER-BROOK \& BARGUES (2002), taking into account the length of ITS2 sequence in rDNA gene, included G. occulta Jackiewicz in a newly established genus Catascopia. They stated after WALTER (1969) that C. occulta was an American species introduced in Europe. Later VINARSKI \& GLÖER (2008) found that although JACKIEWICZ (1992, 1998b) was aware of the occurrence of G. occulta in Siberia, she overlooked that the species discovered by her had been described earlier by WESTERLUND (1885) as Limnaea palustris var. terebra. VINARSKI (2012) moreover argued that Ladislavella B. Dybowski, 1913 was the oldest available name for Catascopia Meier-Brook et Bargues, 2002. Finally, Galba occulta Jackiewicz, 1959 was assigned as a junior synonym of Ladislavella terebra (Westerlund, 1885) (ANDREYEVA et al. 2010, VINARSKI 2012) and this name was used in subsequent publications (e.g. VINARSKI 2012, PIEŃKOWSKA et al. 2014, 2015a, SCHNIEBS 2016, VINARSKI et al. 2016a, PIECHOCKI \& WAWRZYNIAK-WYDROWSKA 2016, SCHNIEBS et al. 2018).

HEBERT et al. (2003a, b) proposed that the nucleotide sequence of the cytochrome oxidase subunit 1 gene (COI) could be a marker that would allow to distinguish species, with suggestion that $3 \%$ genetic distance could be treated as a threshold between separate taxa at the species level. Usefulness of Hebert's barcoding in taxonomy was supported by many authors (e.g. TAUTZ et al. 2003, GREGORY 2005, PACKER et al. 2009, GOLDSTEIN \& DESALLE 2011) with some suggestion that the threshold should be higher for stylommatophoran gastropods (DAVISON et al. 2009, SAUER \& HAUSDORF 2012). However SCHNIEBS et al. (2016) decided that COI sequences could not be used in stagnicoline lymnaeid taxonomy and excluded this gene from their molecular studies (e.g. SCHNIEBS et al. 2015, 2017, 2018, VINARSKI et al. 2017). On the other hand AKSENOVA et al. (2018) presented a deep 
revision of lymnaeid classification with a huge base of $\mathrm{COI}$ sequences for species identifications.

In this paper we compare COI and ITS2 sequences of $L$. terebra specimens from its Siberian and West
Poland populations with the aim of restoring the validity of the taxon described by JACKIEWICZ (1959) to commemorate outstanding achievements in lymnaeid taxonomy of this malacologist who died this year.

\section{MATERIAL AND METHODS}

One hundred and sixty six COI and 31 ITS2 sequences were selected from GenBank resources (Appendix 1). They represented the following lymnaeid species: Ladislavella occulta (Jackiewicz, 1959), L. terebra (Westerlund, 1985), L. exilis (Lea, 1834), L. elodes (Say, 1821), L. tumrokensis (Kruglov et Starobogatov, 1985), Stagnicola palustris (O. F. Müller, 1774), S. corvus (Gmelin, 1791) and Lymnaea stagnalis (Linnaeus, 1758) originating from 61 localities (Appendix 1).

Sequences were prepared using the programme BIOEDIT, version 7.0.5. (HALL 1999). The alignments were performed using the CLUSTAL $\mathrm{W}$ programme (THOMPSON et al. 1994) implemented in BIOEDIT. The ends of all sequences were trimmed to obtain four sets of equal length sequences: COI, ITS2 and COI+ITS2. The lengths of the sequences after cutting were 558 and 461 bp for COI, 488 positions for ITS 2 and 1,014 positions for combined sequences of COI+ITS2 (558 bp +456 positions). The sequences were collapsed to haplotypes (COI) and to common sequences (ITS2 and COI+ITS2) using the programme ALTER (Alignment Transformation EnviRonment) (GLEZ-PEÑA et al. 2010).

During analysis of the phylogenetic relationships, the sequences were analysed by the genetic distance
Neighbour-Joining method (SAITOU \& NEI 1987) implemented in MEGA7 (KUMAR et al. 2016) using the Kimura two-parameter model (K2P) for pairwise distance calculations (KIMURA 1980). Best-fit substitution models were calculated using algorithm implemented in MEGA 7 for every set of sequences independently: Tamura 3 parameter evolutionary model (TAMURA 1992) for COI alignments, Kimura 2-parameter model (KIMURA 1980) for ITS2 set and a HKY substitution model for combined data set of COI+ITS2 (HASEGAWA et al. 1985). For all analyses we assumed a gamma distributed rate variation among sites. Maximum Likelihood analyses were performed using MEGA7.

The ML trees were tested by bootstrap analysis with 1,000 replicates (FELSENSTEIN 1985). In the case of combined alignment COI+ITS2 parallel Bayesian Interference was conducted using the programme MRBAYES 3.1.2 (RONQUIST \& HUELSENBECK 2003). Four Monte Carlo Markov chains were run for 1 million generations, sampling every 100 generations (the first 250,000 trees were discarded as 'burn-in'). This yielded a $50 \%$ majority rule consensus tree. Finally, calculated during ML analysis bootstrap values were mapped on the $50 \%$ majority rule consensus Bayesian tree.

\section{RESULTS}

The COI sequences obtained from GenBank were attributed to 77 haplotypes (Appendix 1). They had to be trimmed so that they could be aligned for the construction of ML trees. The tree of 53 haplotypes (558 bp long, COI 1 - COI 53) is shown in Fig. 1. The haplotypes clustered in nine clades, namely Ladislavella occulta, L. terebra, L. liogyra, L. exilis, $L$. elodes/tumrokensis, Stagnicola palustris (1), S. corvus, S. palustris (2) and Lymnaea stagnalis. The K2P genetic distances within these clades were very small, within a range of $0.0-2.0 \%$ (mean values) except for $S$. palustris (1) and (2) (when they were treated as one taxon, $4.1 \%)$ and L. stagnalis $(4.4 \%)$ (Table 1$)$. The K2P distances between clades were usually larger than $10 \%$ when they were compared in pairs (Table 1 ) with some exceptions, like $L$. tumrokensis vs. $L$. elodes which differed at the level of "within clade" distances $(2.3 \%)$. Also, smaller distances separated pairs $L$. terebra vs. L. liogyra $(6.9 \%)$, L. exilis vs. $L$. tumrokensis $(6.1 \%)$, L. exilis vs. L. elodes $(6.3 \%)$ and S. palustris (2) vs. S. corvus (6.0\%). Other K2P distances were larger, however these between clades representing the same genus were smaller (in the range $6.3-15.8 \%$ and $7.8 \%$ within Ladislavella and Stagnicola, respectively) than those between clades of different genera (Ladislavella vs. Stagnicola 18.3$22.0 \%$ and Ladislavella vs. Lymnaea 19.5-20.7\%, however the K2P distances were $13.9-15.1 \%$ for Stagnicola vs. Lymnaea).

To compare the above haplotypes with eighty COI sequences for Hinkleya caperata and one for L. elodes deposited in GenBank by MORNINGSTAR et al. (2018) and DEWAARD et al. (2014), respectively (24 additional halotypes COI 54 - COI 77), they all had to be trimmed to $461 \mathrm{bp}$ long haplotypes. The resulting ML tree (Fig. 2) showed similar clades as for longer haplotypes (Fig. 1) with one additional clade of haplotypes characteristic of $H$. caperata. 


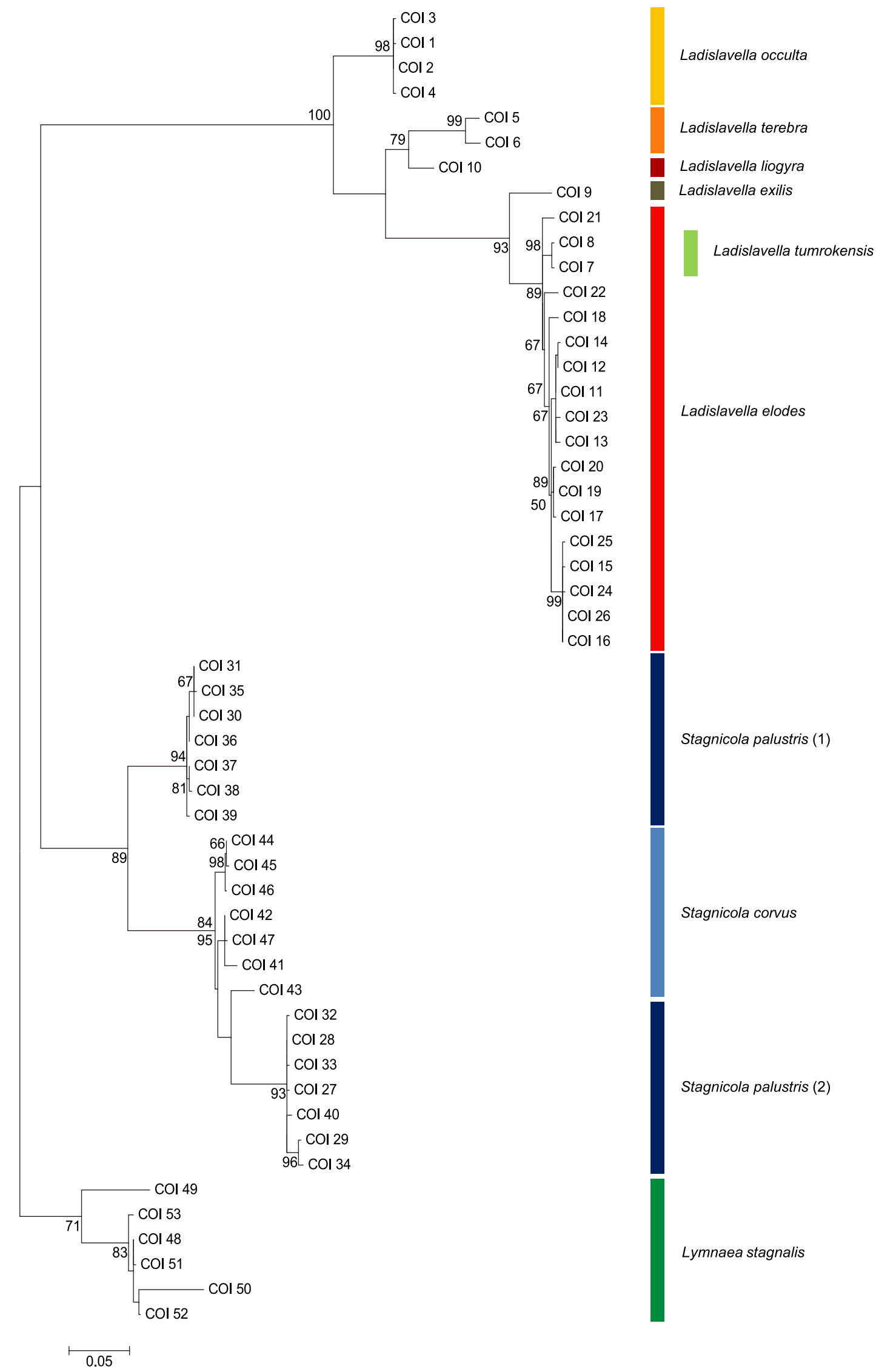

Fig. 1. Maximum Likelihood (ML) tree of the 558-bp-long fragment of COI sequences of the studied lymnaeid species with the use of Lymnaea stagnalis as outgroup (see Appendix 1). Numbers on branches represent bootstrap support above $50 \%$ 
The ITS2 sequences obtained from GenBank were attributed to 23 common sequences (Appendix 1). They clustered in seven clades on the ML tree (Fig. 3), three (S. corvus, S. palustris and L. stagnalis) clearly and four (L. occulta, L. terebra, L. elodes and L. tum- rokensis) less separated. The smallest K2P distances (Table 1) differentiated specimens within particular species (mean values up to $1.6 \%$ ), except $L$. terebra with its intraspecific variation larger $(5.3 \%)$. The largest K2P distances were between species included

Table 1. Ranges of K2P genetic distances for COI and ITS2 sequences analysed (mean values in parentheses)

\begin{tabular}{|c|c|c|}
\hline Comparison & $\mathrm{COI}(\%)$ & ITS2 (\%) \\
\hline Within L. occulta & $0.2-0.4(0.3)$ & 0.0 \\
\hline Within L. terebra & 2.2 & 5.3 \\
\hline Within L. liogyra & 0.0 & \\
\hline Within L. exilis & 0.0 & \\
\hline Within L. tumrokensis & 0.4 & 0 \\
\hline Within L. elodes & $0.2-2.8(1.4)$ & 0.8 \\
\hline Within S. palustris & $0.2-11.9(4.1)$ & $0.2-1.4(0.9)$ \\
\hline Within S. palustris (1) & $0.2-1.1(0.6)$ & \\
\hline Within S. palustris (2) & $0.2-1.5(0.9)$ & \\
\hline Within S. corvus & $0.2-4.1(2.0)$ & $1.2-2.4(1.6)$ \\
\hline Within L. stagnalis & $0.7-10.4(4.4)$ & $0.5-2.3(1.2)$ \\
\hline Between L. occulta and L. terebra & $12.2-12.8(12.6)$ & $2.4-6.4(4.4)$ \\
\hline Between L. occulta and L. liogyra & $10.0-10.2(10.2)$ & \\
\hline Between L. occulta and L. exilis & $15.0-15.5(15.3)$ & \\
\hline Between L. occulta and L. tumrokensis & $15.0-15.5(15.3)$ & 6.8 \\
\hline Between L. occulta and L. elodes & $14.5-16.9(15.8)$ & $6.8-7.1(7.0)$ \\
\hline Between L. occulta and S. palustris & $19.7-21.4(20.5)$ & $29.8-32.1(31.0)$ \\
\hline Between L. occulta and S. corvus & 18.5-20.9 (19.6) & $31.0-31.8(31.5)$ \\
\hline Between L. occulta and L. stagnalis & 18.5-21.4 (19.9) & $34.0-34.4(34.1)$ \\
\hline Between L. terebra and L. liogyra & 6.9 & \\
\hline Between $L$. terebra and L. exilis & $12.3-13.4(12.9)$ & \\
\hline Between L. terebra and L. tumrokensis & $13.7-15.1(14.4)$ & $6.2-10.3(8.3)$ \\
\hline Between L. terebra and L. elodes & $13.5-16.1(15.1)$ & $6.2-10.3(8.1)$ \\
\hline Between $L$. terebra and S. palustris & $20.6-22.8(21.6)$ & $32.0-38.6(35.4)$ \\
\hline Between L. terebra and S. corvus & $19.9-21.3(20.5)$ & $32.2-39.0(35.5)$ \\
\hline Between $L$. terebra and $L$. stagnalis & $18.7-22.6(20.6)$ & $35.5-40.7(37.9)$ \\
\hline Between L. liogyra and L. exilis & 11.9 & \\
\hline Between L. liogyra and L. tumrokensis & 12.1 & \\
\hline Between L. liogyra and L. elodes & $12.3-13.0(12.7)$ & \\
\hline Between L. liogyra and S. palustris & $20.6-21.8(21.1)$ & \\
\hline Between L. liogyra and S. corvus & $20.4-22.1(20.8)$ & \\
\hline Between L. liogyra and L. stagnalis & $18.5-21.6(20.0)$ & \\
\hline Between L. exilis and $L$. tumrokensis & 6.1 & \\
\hline Between $L$. exilis and $L$. elodes & $5.5-6.7(6.3)$ & \\
\hline Between L. exilis and S. palustris & 18.9-19.7 (19.4) & \\
\hline Between L. exilis and S. corvus & 18.0-19.0 (18.3) & \\
\hline Between L. exilis and L. stagnalis & $17.5-21.6(19.5)$ & \\
\hline Between L. tumrokensis and L. elodes & $1.8-2.8(2.3)$ & $0.5-0.8(0.6)$ \\
\hline Between L. tumrokensis and S. palustris & $21.2-22.4(21.8)$ & $32.5-34.9(34.0)$ \\
\hline Between L. tumrokensis and S. corvus & 20.7-21.4 (21.1) & $34.9-36.6(35.8)$ \\
\hline Between L. tumrokensis and L. stagnalis & $19.9-22.4(20.8)$ & $36.7-38.1(37.1)$ \\
\hline Between L. elodes and S. palustris & $20.2-23.5(22.0)$ & $32.2-34.6(33.7)$ \\
\hline Between L. elodes and S. corvus & 19.9-22.7 (21.2) & $34.6-36.3(35.5)$ \\
\hline Between L. elodes and L. stagnalis & $19.0-23.1(20.7)$ & $35.6-38.1(36.5)$ \\
\hline Between S. palustris and S. corvus & $5.1-11.6(7.8)$ & $5.0-6.5(5.9)$ \\
\hline Between S. palustris and L. stagnalis & $11.8-17.4(13.9)$ & $9.5-12.3(10.8)$ \\
\hline Between S. corvus and L. stagnalis & $14.0-17.1(15.1)$ & $12.2-13.8(13.1)$ \\
\hline
\end{tabular}




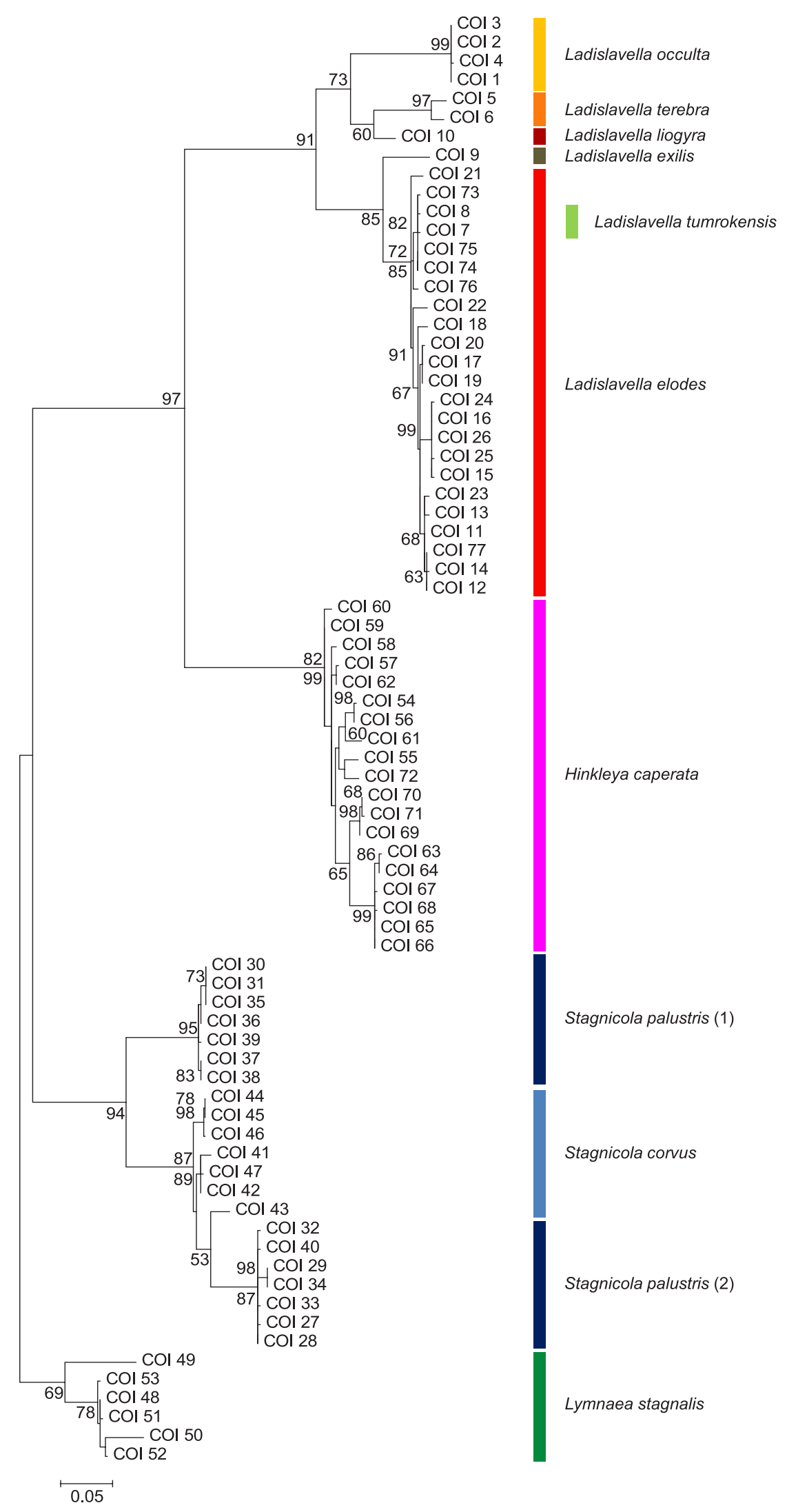

Fig. 2. Maximum Likelihood (ML) tree of the 461-bp-long fragment of COI sequences of the studied lymnaeid species with the use of $L$. stagnalis as outgroup (see Appendix 1). Shortening the length of the sequences within alingment allowed to add sequences of Hinkleya caperata to the phylogenetic analysis. Numbers on branches indicate bootstrap support above $50 \%$ 


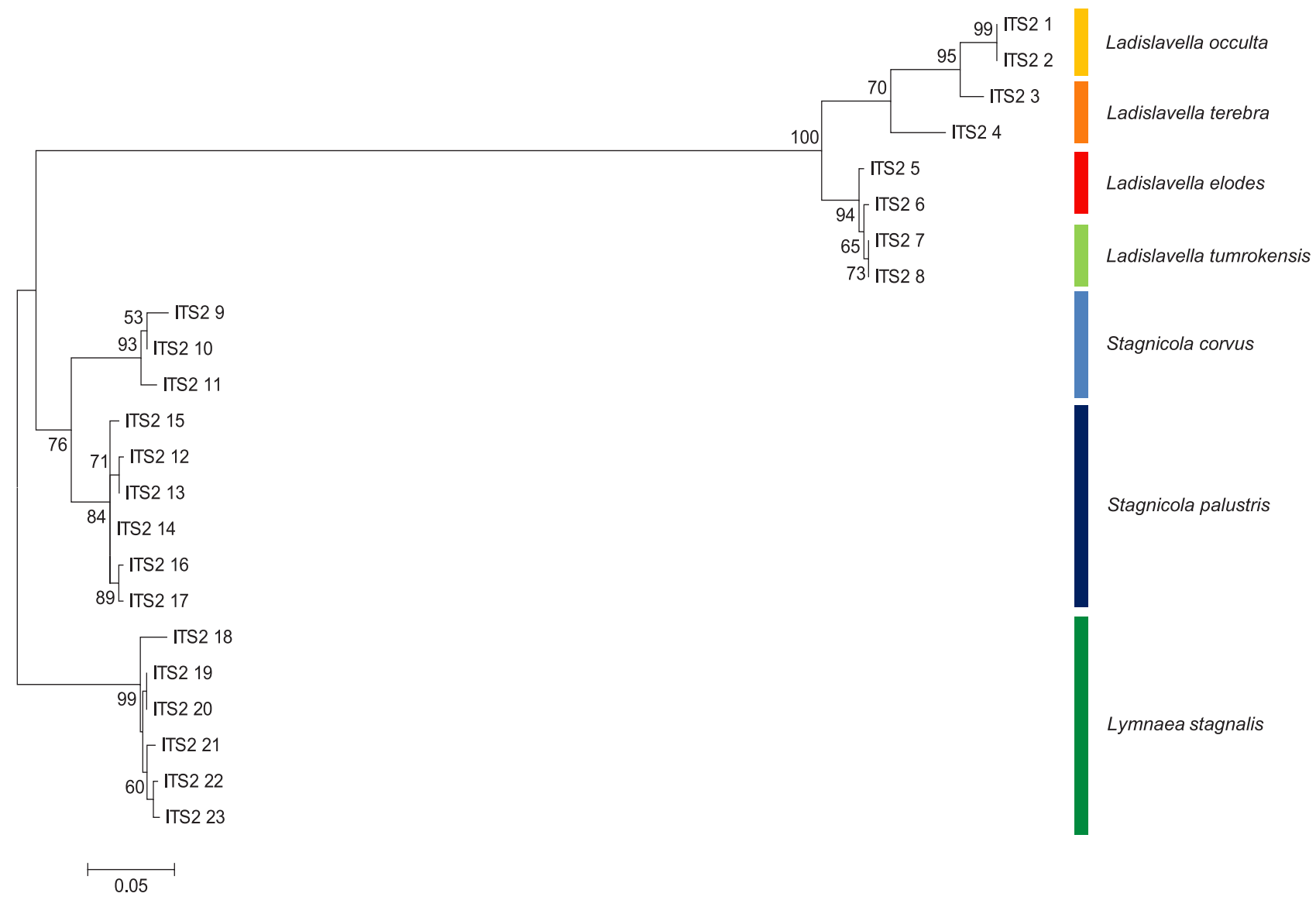

Fig. 3. Maximum Likelihood (ML) tree of the 488-position-long fragment of ITS2 sequences of the studied lymnaeid species with the use of $L$. stagnalis as outgroup (see Appendix 1). Numbers on branches indicate bootstrap support above $50 \%$

Table 2. Number of differences in ITS2 nucleotide sequences between analysed species of genus Ladislavella

\begin{tabular}{|c|c|c|c|c|}
\hline & \multicolumn{4}{|c|}{ Number of nucleotide sequence differences } \\
\hline & \multirow{2}{*}{ Total } & \multicolumn{2}{|c|}{ Substitutions } & \multirow{2}{*}{ Insertions + deletions } \\
\hline & & Transitions & Transversions & \\
\hline L. occulta (ITS2 1 \& 2) vs. L. terebra (ITS2 3 \& 4) & $43-59$ & $2-11$ & $7-13$ & $19-50$ \\
\hline L. occulta (ITS2 1 \& 2) vs. L. elodes (ITS2 5 \& 6) & $80-86$ & $11-12$ & $12-13$ & $56-61$ \\
\hline L. occulta (ITS2 $1 \&$ 2) vs. L. tumrokensis (ITS2 $7 \& 8$ ) & $87-89$ & 11 & $13-14$ & $62-64$ \\
\hline L. terebra (ITS2 3 \& 4) vs. L. elodes (ITS2 5 \& 6) & $62-89$ & $13-20$ & $9-17$ & $28-66$ \\
\hline L. terebra (ITS2 3 \& 4) vs. L. tumrokensis (ITS2 $7 \& 8$ ) & $68-91$ & $12-19$ & $10-19$ & $30-69$ \\
\hline L. elodes (ITS2 5 \& 6) vs. L. tumrokensis (ITS2 $7 \& 8$ ) & $4-10$ & $0-2$ & $1-2$ & $2-7$ \\
\hline
\end{tabular}

Table 3. Combined sequences of COI and ITS2 fragments for Bayesian analysis

\begin{tabular}{llll}
\hline \multicolumn{1}{c}{ Species } & Combined sequences & COI & ITS2 \\
\hline Ladislavella occulta & CS 1 & KP070796 & HP070772 \\
Ladislavella terebra & CS 2 & LT623591 & HE613324 \\
& CS 3 & LT623592 & KP830108 \\
Ladislavella tumrokensis & CS 4 & KP830102 & KP830109 \\
Stagnicola corvus & CS 5 & KP830103 & KP070771 \\
Stagnicola palustris & CS 6 & KP070781 & KP070769 \\
Lymnaea stagnalis & CS 7 & KP070773 & FR797836 \\
& CS 8 & FR797867 & HG931958 \\
& CS 9 & HG932251 & HG931952 \\
& CS 10 & HG932247 & HG931965 \\
\hline
\end{tabular}




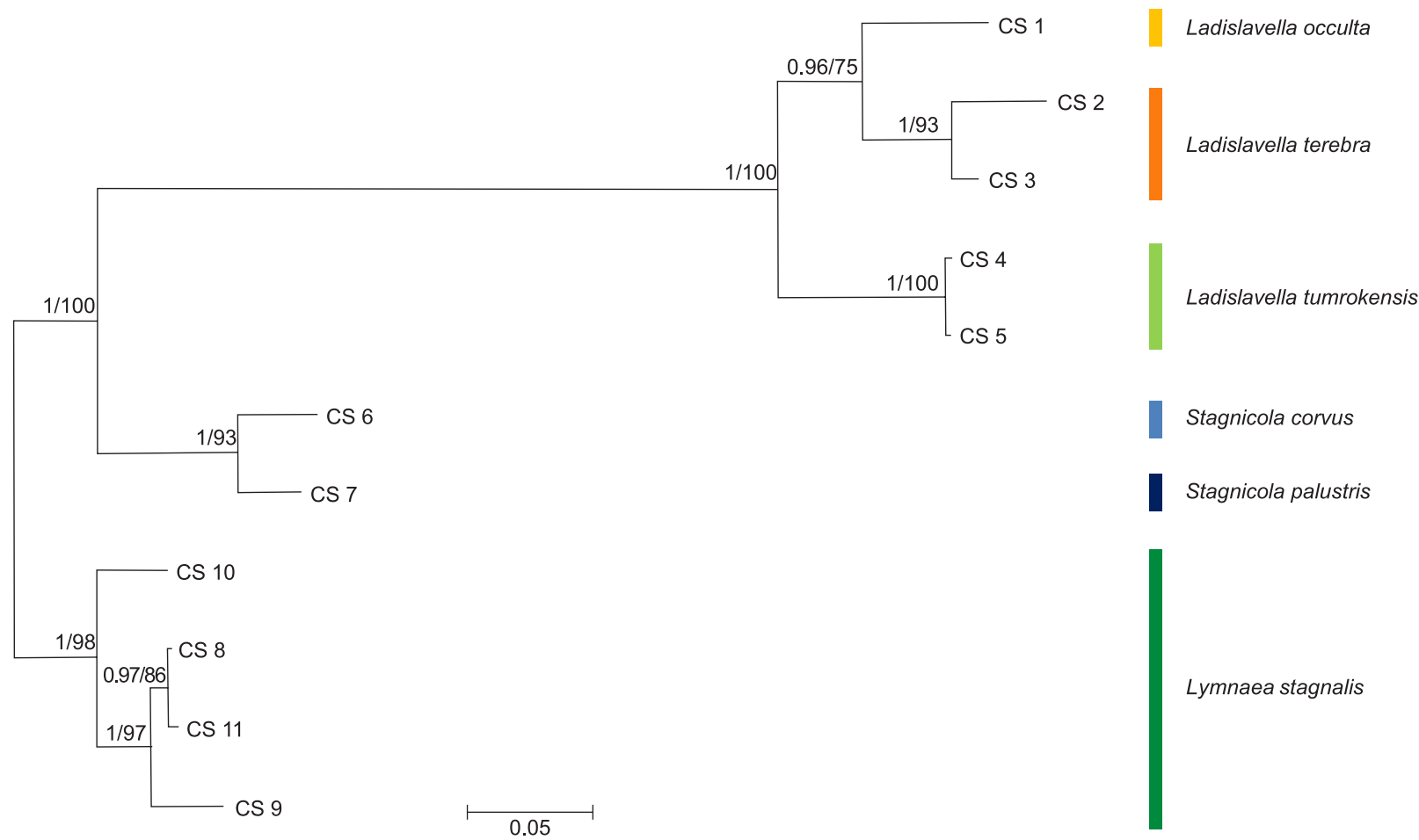

Fig. 4. Majority-rule consensus tree obtained from Bayesian Inference analysis (BI) of the combined data set of COI and ITS2 DNA sequences (see Table 3) of the studied lymnaeid species. The tree was rooted with L. stagnalis combined sequences. Posterior probabilities (left) and bootstrap support above 50\% from ML analysis (right) are marked on branches

in Stagnicola and Lymnaea clades and those grouped in four Ladislavella clades analysed in pairs (mean values $31.0-37.9 \%$ ). Mean values of the K2P distance within Ladislavella species support their separation (L. occulta vs. L. terebra $4.4 \%, L$. occulta vs. L. tumrokensis $6.8 \%$, L. occulta vs. L. elodes $7.0 \%$, L. terebra vs. $L$. tumrokensis $8.3 \%$, L. terebra vs. L. elodes $8.1 \%$ ), except a pair L. tumrokensis and L. elodes (mean K2P distance $0.6 \%$ ). It is noteworthy that the number of differences between ITS2 sequences of $L$. occulta and $L$. terebra is smaller than those distinguishing L. occulta from $L$. elodes and L. tumrokensis as well as L. terebra from L. elodes and L. tumrokensis (Table 2). However it is much larger than the number differences in ITS2 sequences between L. elodes and L. tumrokensis (Table 2) and much smaller than between L. occulta or L. terebra and species of Stagnicola or Lymnaea (data not shown).

Ten ITS2 sequences deposited in GenBank for lymnaeids made it possible to create combined sequences COI + ITS2 (Table 3). The Bayesian inference tree resulted in six well separated clades $L$. occulta, L. terebra, L. tumrokensis, S. palustris, S. corvus and L. stagnalis (Fig. 4).

\section{DISCUSSION}

No differences were found in the structure of the shell and reproductive system between topotypical material of Galba occulta Jackiewicz and Siberian Limnaea palustris var. terebra Westerlund in careful comparative studies (VINARSKI 2003, 2012, VINARSKI \& GLÖER 2008). Moreover, specimens of both species were closely related based on their ITS2 sequences in $r D N A$ gene (VINARSKI et al. 2016a). Therefore VINARSKI \& GLÖER (2008) synonymised the taxa giving a priority to the older name. Somewhat later VINARSKI (2012) assigned it to the genus Ladislavella B. Dybowski, 1913 as L. terebra (Westerlund, 1885).

We found that the specimens from the Polish population in Gorzykowo near Gniezno (W. Poland) differed in their nucleotide sequences of $\mathrm{COI}$ and ITS2 fragments from the two Siberian populations (Tjumen Region and Altai Republic, Russia) (Figs 1-4). The K2P distances between the common sequences of ITS2 fragment suggest that these populations are closely related (as suggested by VINARSKI et al. 2016a). However the differences of ITS2 sequences between the Altai and Tjumen populations require further in-depth research on a larger number of populations. On the other hand, K2P distances between the haplotypes COI $1-$ COI 4 and COI 5 \& COI 6 , representing these two groups (Polish and Siberian), respectively, are much higher (12.2-12.8\%) than the $3 \%$ threshold established by HEBERT et al. (2003a, 
b) for species delimitation. We are aware of the objections to the use of Hebert's threshold (DAVISON et al. 2009, SAUER \& HAUSDORF 2012 and references cited therein). Moreover we have always stressed (PIEŃKOWSKA et al. 2015b, 2018a, b) that molecular features alone are not enough for species designation and that they have to be supported by anatomical features. However, the Polish and Siberian populations are far away from each other and one can expect a process of speciation that has a faster expression in the features of the rapidly evolving mitochondrial genome (THOMAZ et al. 1996, REMigio \& HeBert 2003) than, for example, in the features of shell and genitalia. Therefore we propose to retain the species name introduced by JACKIEWICZ (1959), i.e. L. occul$t a$, for the Polish lineage of the taxon, especially when the other valid species of the genus Ladislavella differ to a lesser extent in the nucleotide sequence of the COI gene than L. occulta and L. terebra (see Table 1).

L. occulta or L. terebra were identified on the basis of shell and genital system features from several localities from Europe (West Poland, South Sweden, Czech Republic, Bosnia-Hercegovina, Ukraine) and Siberia (Yeniseysk and Selenga River near Baikal lake) by JACKIEWICZ (1992, 1993, 1997, 1998a, b) (who used the name Lymnaea (Stagnicola) occulta); several localities in Germany and Rusia (especially in Siberia and Far East) were added to its distribution by VINARSKI \& GLÖER (2008) and recently from Ukraine (Khust district) by ANISTRATENKO et al. (2018) (using the name Ladislavella terebra). However L. occulta or L. terebra at these localities were identified on the basis of shell and genital system features. We report differences in COI and ITS2 sequences between one Polish (Gorzykowo, W. Poland) and two Russian (Siberia) localities. Further molecular research on L. occulta and L. terebra populations from other localities is necessary. Unfortunately all but one (Gorzykowo) Polish localities found by Jackiewicz and her co-workers (JACKIEWICZ 1959, 1993, 1998a, 2000) were destroyed, so the Polish L. occulta lineage is threatened with extinction (RYBSKA et al. 2007).

\section{REFERENCES}

AKsenova O. V., Bolotov I. N., Gofarov M. YU., KONDAKOV A. V., VINARSKI M. V., BESPALAYA Y. V., Kolosova Y. S., Palatov D. M., SOKOlOVA S. E., SPITSYN V. M., TOMILOVA A. A., TRAVINA O. V., VIKHREV I. V. 2018. Species richness, molecular taxonomy and biogeography of the radicine pond snails (Gastropoda: Lymnaeidae) in the Old World. Scientific Reports 8: 11199. https://doi.org/10.1038/s41598-018-29451-1

ANDREYEVA S. I., ANDREYEV N. I., VINARSKI M. V. 2010. Opriedielitiel presnovodnykh briukhonogikh mollyuskov (Mollusca: Gastropoda) Zapadnoy Sibiri. V. 1.
Although this was not the aim of this study, we add a few remarks about lymnaeid taxa resulting from our analysis of the COI gene sequences:

1. COI gene sequences well support the generic classification of the following taxa: Ladislavella B. Dybowski, 1913, Hinkleyia F. C. Baker, 1928, Stagnicola Jeffreys, 1830 and Lymnaea Lamarck, 1799.

2. The results of this paper support the suggestion that L. tumrokensis and L. elodes are conspecific (according to VINARSKI et al. 2017 they represent two subspecies of Ladislavella catascopium).

3. The status of Stagnicola palustris should be verified. We found that this species was represented by two different COI lineages. SCHNIEBS et al. (2016) pointed to the inconsistency of stagnicoline lymnaeid classification based on mitochondrial sequences vs. that resulting from the analysis of nuclear genes and reproductive system anatomy. Drawing conclusions on the basis of our results would be premature. Further research is needed on a larger number of $S$. palustris populations to determine if this difference in COI sequences is a result of interspecific hybridisation or speciation visible in the mitochondrial genome.

4. Although Lymnaea stagnalis is a well defined species, it is also greatly diversified in COI nucleotide sequences which suggests that further studies on its populations would be necessary.

\section{ACKNOWLEDGEMENTS}

The authors are deeply indebted to KATRIN SCHNIEBS (Senckenberg Natural History Collections Dresden, Germany) for providing unpublished data concerning some localities of lymnaeid populations and to Professor WoJCIECH NiEdbaŁA (Department of Animal Taxonomy and Ecology, Adam Mickiewicz University, Poznań) for his useful comments on the manuscript.

Gastropoda: Pulmonata. No. 1. Siemiestva Acroloxidae i Lymnaeidae. GP Omskaya oblastnaya tipografia, Omsk.

ANISTRATENKO V. V., ViNARSKi M. V., ANISTRATENKO O. YU., FURYK YU. I., DEGTYARENKO E. V. 2018. New data on pond snails (Mollusca: Gastropoda: Lymnaeidae) inhabiting the Ukrainian Transcarpathian: diversity, distribution and ecology. Ecologica Montenegrina 18: 1-14.

Bargues M. D., Horák P., Patzner R. A., Pointier J. P., JACKIEWICZ M., MEIER-BroOK C., MAS-COMA S. 2003. 
Insights into the relationships of Palearctic and Nearctic lymnaeids (Mollusca: Gastropoda) by rDNA ITS-2 sequencing and phylogeny of stagnicoline intermediate host species of Fasciola hepatica. Parasite 10: 243-255. https://doi.org/10.1051/parasite/2003103243

BARgues M. D., Vigo M., HorÁK P., DVORAK J., PATZNER R. A., POINTIER J. P., JACKIEWICZ M., MEIER-BROOK C., MAS-COMA S. 2001. European Lymnaeidae (Mollusca: Gastropoda), intermediate hosts of trematodiases, based on nuclear ribosomal DNA ITS-2 sequences. Infection, Genetics and Evolution 1: 85-107. https:// doi.org/10.1016/S1567-1348(01)00019-3

CAmpbell D. C., Clark S. A., Lydeard C. 2017. Phylogenetic analysis of the Lancinae (Gastropoda, Lymnaeidae) with a description of the U. S. federally endangered Banbury Springs lanx. ZooKeys 663: 107132. https://doi.org/10.3897/zookeys.663.11320

DAVISON A., BLACKIE R. L., SCOTHERN G. P. 2009. DNA barcoding of stylommatophoran land snail: a test of existing sequences. Molecular Ecology Resources 9: 1092-1101. https://doi.org/10.1111/j.1755-0998.2009.02559.x

Dayrat B., CONRAD M., Balayan S., White T. R., ALbreCHT C., GOLDING R., GOMES S. R., HARASEWYCH M. G., DE Frias MARTINS A. M. 2011. Phylogenetic relationships and evolution of pulmonate gastropods (Mollusca): new insights from increased taxon sampling. Molecular Phylogenetics and Evolution 59: 425437. https://doi.org/10.1016/j.ympev.2011.02.014

DeWaARD J. R. 2017. Canadian National Parks Data Release. Sequences available online at GenBank https://www.ncbi.nlm.nih.gov/genbank/ (accessed 30 October 2018)

DeWAard J. R., Telfer A., Young M. R. 2014. Barcoding Canada data release. Sequences available online at GenBank https://www.ncbi.nlm.nih.gov/genbank/ (accessed 21 October 2018)

FALKNER G. 1995. Present-day knowledge on the systematics of the genus Stagnicola in Europe. In: GUERRA A., ROLAN E., ROCHA F. (eds). Abstracts 12th International Malacological Congress, Vigo, Spain 1995: 378-379.

FALKNER G., BANK R., PROSCHWITZ T. vON 2001. Checklist of the non-marine molluscan species-group taxa of the states of Northern, Atlantic and Central Europe (CLECOM I). Heldia 4: 1-76.

FELSENSTEIN J. 1985. Confidence limits on phylogenies: an approach using the bootstrap. Evolution 39: 783-791. https://doi.org/10.1111/j.1558-5646.1985.tb00420.x

Glez-PeÑa D., GómeZ-BlanCO D., Reboiro-JATO M., FdeZ-Riverola F., PosadA D. 2010. AlTER: program-oriented format conversion of DNA and protein alignments. Nucleic Acids Research 38 (Web Server issue): W14-W18. https://doi.org/10.1093/nar/gkq321

GLÖER P. 2002. Die Süßwassergastropoden Nord- und Mitteleuropas. Die Tierwelt Deutschlands 73. Conchbooks, Hackenheim.

GLÖER P., MEIER-BROOK C. 2003. Süßwassermollusken. 13 Ed. Deutscher Jugendbund für Naturbeobachtung, Hamburg.

GoldsteIN P. Z., DeSAlle R. 2011. Integrating DNA barcode data and taxonomic practise: determination, discovery, and description. BioEssays 33: 135-147. https://doi.org/10.1002/bies.201000036

Gordy M. A., Kish L., TARRABain M., HANington P. C. 2016. A comprehensive survey of larval digenean trematodes and their snail hosts in central Alberta, Canada. Parasitology Research 115: 3867-3880. https://doi. org/10.1007/s00436-016-5152-9

GREGORY T. R. 2005. DNA barcoding does not compete with taxonomy. Nature 434: 1067-1068. https://doi. org/10.1038/4341067b

Hall T. A. 1999. BioEdit: a user friendly biological sequence alignment editor and analysis program for Windows 95/98/NT. Nucleic Acids Symposium Series 41: 95-98. http://brownlab.mbio.ncsu.edu/JWB/papers/1999Hall1.pdf

HASEGAWA M., KisHiNO H., YANO T. 1985. Dating the human-ape split by a molecular clock of mitochondrial DNA. Journal of Molecular Evolution 22: 160-174. https://doi.org/10.1007/BF02101694

Hebert P. D. N., CYWinska A., Ball S. L., DeWAard J. R. 2003a. Biological identifications through DNA bardcodes. Proceedings of the Royal Society B: Biological Sciences 270: 313-321. https://doi.org/10.1098/ rspb.2002.2218

HeBert P. D. N., RATNASINGHAM S., DEWAARD J. R. 2003 b. Barcoding animal life: cytochrome c oxidase subunit 1 divergences among closely related species. Proceedings of the Royal Society B: Biological Sciences 270 (Suppl. 1): 596-599. https://doi.org/10.1098/rsbl.2003.0025

IBOL DATA RELEASE 2011. International Barcode of Life (iBOL). Sequences available online at GenBank https:// www.ncbi.nlm.nih.gov/genbank/ (accessed 21 October 2018).

JACKIEWICZ M. 1959. Badania nad zmiennością i stanowiskiem systematycznym Galba palustris O. F. Müll. Prace Komisji Biologicznej PTPN 19: 89-187.

JACKIEWICZ M. 1992. Lymnaea (Stagnicola) occulta (Jackiewicz, 1959) (Gastropoda: Pulmonata) in Sibirien. Mitteilungen der Deutschen Malakozoologischen Gesellschaft 49: 13-16.

JACKIEWICZ M. 1993. Phylogeny and relationships within the European species of the family Lymnaeidae (Gastropoda: Pulmonata: Basommatophora). Folia Malacologica 5: 61-95. https://doi.org/10.12657/folmal.005.003

JACKIEWICZ M. 1997. New European locality of Lymnaea (Stagnicola) occulta (Jackiewicz, 1959) (Gastropoda, Pulmonata, Basommatophora). Malakologische Abhandlungen Staatliches Museum für Tierkunde Dresden 18: 255-259.

JACKIEWICZ M. 1998a. European species of the family Lymnaeidae (Gastropoda, Basommatophora: Pulmonata). Genus 9: 1-93.

JACKIEWICZ M. 1998b. Lymnaea (Stagnicola) occulta (Jackiewicz, 1959) in the Selenga River delta at the Baikal Lake (Siberia) (Gastropoda, Basommatophora, Lymnaeidae). Malakologische Abhandlungen Staatliches Museum für Tierkunde Dresden 19: 53-57.

JACKIEWICZ M. 2000. Błotniarki Europy (Gastropoda: Pulmonata: Lymnaeidae). Wydawnictwo Kontekst, Poznań. 
KIMURA M. 1980. A simple method for estimating evolutionary rate of base substitutions through comparative studies of nucleotide sequences. Journal of Molecular Evolution 16: 111-120. https://doi.org/10.1007/ BF01731581

KUMAR S., STECHER G., TAMURA K. 2016. MEGA7: Molecular Evolutionary Genetics Analysis version 7.0 for bigger datasets. Molecular Biology and Evolution 33: 1870-1874. https://doi.org/10.1093/molbev/ msw054

Meier-BrooK C., BArgues M. D. 2002. Catascopia, a new genus for three nearctic and one palearctic Stagnicola species (Gastropoda, Lymnaeidae). Folia Malacologica 10: 83-84. https://doi.org/10.12657/folmal.010.008

Morningstar C. R., InOUe K., LANG B. K., Berg D. J. 2018. A comprehensive status, phylogenetic, and anatomical review of Stagnicola caperata (Say, 1829) in the south-west United States. Aquatic Conservation: Marine and Freshwater Ecosystems 28: 527-534. https://doi.org/10.1002/aqc.2859

NOVOBILSKY A., KAšNY M., BERAN L., RONDELAUD D., HoGLUND J. 2013. Lymnaea palustris and Lymnaea fuscus are potential but uncommon intermediate hosts of Fasciola hepatica in Sweden. Parasites \& Vectors 6: 251 (1-10). https://doi.org/10.1186/1756-3305-6-251

PACKer L., Grixti J. C., Roughley R. E., HANNer R. 2009. The status of taxonomy in Canada and the impact of DNA barcoding. Canadian Journal of Zoology 87: 1097-1110. https://doi.org/10.1139/Z09-100

PIECHOCKI A., WAWRZYNIAK-WYDROWSKA B. 2016. Guide to freshwater and marine Mollusca of Poland. Bogucki Wydawnictwo Naukowe, Poznań.

PieńKOWSKA J. R., Giusti F., MANGANELli G., LESICKI A. 2015b. Monacha claustralis (Rossmässler 1834) new to Polish and Czech malacofauna (Gastropoda: Pulmonata: Hygromiidae). Journal of Conchology 42: 79-93. http://docplayer.net/56112556-Monacha-claustralis-rossmassler-1834-new-to-polish-and-czech-malacofauna-gastropoda-pulmonata-hygromiidae.html

PIEŃKOWSKA J. R., KosickA E., WOJTKOWSKA M., KMITA H., LESICKI A. 2014. Molecular identification of first putative aquaporins in snails. Journal of Membrane Biology 247: 239-252. https://doi.org/10.1007/ s00232-014-9629-0

PieńKOWSKa J. R., MANGANELli G., GiUsti F., Hallgass A., LESICKI A. 2018a. Exploring Monacha cantiana (Montagu, 1803) phylogeography: cryptic lineages and new insights into the origin of the English populations (Eupulmonata, Stylommatophora, Hygromiidae). ZooKyes 765: 1-41. https://doi.org/10.3897/zookeys.765.24386

PieńKOWSKa J. R., MANGANELli G., GiUsti F., Robato D., HALlGASS A., LESICKI A. 2018b. Exploration of phylogeography of Monacha cantiana s. 1. continues: the populations of the Apuan Alps (NW Tuscany, Italy) (Eupulmonata, Stylommatophora, Hygromiidae). ZooKeys (accepted)

PIEŃKOWSKA J. R., RYBSKA E., BANASIAK J., WESOŁOWSKA M., LESICKI A. 2015a. Taxonomic status of Stagnicola palustris (O. F. Müller, 1774) and S. turricula (Held, 1836) (Gastropoda: Pulmonata: Lymnaeidae) in view of new molecular and chorological data. Folia Malacologica 23: 3-18. https://doi.org/10.12657/folmal.023.003

Remigio E. A., Hebert P. D. N. 2003. Testing the utility of partial COI sequences for phylogenetic estimates of gastropod relationships. Molecular Phylogenetics and Evolution 29: 641-647. https://doi.org/10.1016/ S1055-7903(03)00140-4

RONQUiST F., HUELSENBECK J. P. 2003. MRBAYES 3: Bayesian phylogenetic inference under mixed models. Bioinformatics 19: 1572-1574. https://doi. org/10.1093/bioinformatics/btg180

RYBSKA E., KSIĄŻKIEWICZ Z., GŁAZACZOW A., ORWIN D., BAJACZYK R., LESICKI A. 2007. The rare lymnaeid species Stagnicola occulta (Pulmonata: Lymnaeidae) is disappearing from the waters of the Wielkopolska region (W. Poland). The Freshwater Biological Association Annual Scientific Meeting, Windermere 5-6 September 2007, Book of Abstracts: 14.

SAITOU N., NEI M. 1987. The neighbor-joining method: a new method for reconstructing phylogenetic trees. Molecular Biology and Evolution 4: 406-425. https:// doi.org/10.1093/oxfordjournals.molbev.a040454

SAUER J., HAUSDORF B. 2012. A comparison of DNA-based methods for delimiting species in a Cretan land snail radiation reveals shortcomings of exclusively molecular taxonomy. Cladistics 28: 300-316. https://doi. org/10.1111/j.1096-0031.2011.00382.x

SCHNIEBS K. 2016. Beiträge zur Systematik und Taxonomie paläarktischer Schlammschnecken (Gastropoda, Basommatophora, Lymnaeidae) anhand molekulargenetischer und morphologischer Merkmale. Ph. D. Thesis, Fakultät Umweltwissenschaften, Technische Universität Dresden.

Schniebs K., GeORgIEV D., GlÖER P., HundsDoerfer A. K. 2015. A molecular genetic evidence of the occurrence of the freshwater snail Radix lagotis (Schrank, 1803) (Gastropoda: Lymnaeidae) in Bulgaria. Ecologica Montenegrina 3: 29-39.

SCHNiEBs K., GlÖER P., GeORgIEV D., Hundsdoerfer A. K. 2012. First record of Stagnicola montenegrinus Glöer \& Pešić, 2009 (Mollusca: Gastropoda: Lymnaeidae) in Bulgaria and its taxonomic relationship to other European lymnaeids based on molecular analysis. North-Western Journal of Zoology 8: 164-171.

SCHNIEBS K., GLÖER P., QUIÑONERO-SALGADO S., LOPEZSORIANO J., HundSDOERFER A. K. 2018. First record of freshwater snail Galba cubensis (L. Pfeiffer, 1839) (Mollusca, Gastropoda, Lymnaeidae) from Europe in the open fields. Folia Malacologica 26: 3-15. https:// doi.org/10.12657/folmal.026.002

SCHNIEBS K., GLÖER P., VINARSKI M. V., HUNDSDOERFER A. K. 2011. Intraspecific morphological and genetic variability in Radix balthica (Linnaeus 1758) (Gastropoda: Basommatophora: Lymnaeidae) with morphological comparison to other European Radix species. Journal of Conchology 40: 657-678.

SCHNIEBS K., GLÖER P., VINARSKI M. V., HUNDSDOERFER A. K. 2016. A barcode pitfall in Palaearctic Stagnicola specimens (Mollusca: Lymnaeidae): incongruence of mitochondrial genes, a nuclear marker and morphology. North-Western Journal of Zoology 12: 239-254. 
http://biozoojournals.ro/nwjz/content/v12n2/nwjz e151314_Schniebs.pdf

SCHNIEBS K., GLÖER P., VINARSKI M., QUIÑONERO-SALGADO S., LOPEZ-SORIANO J., HUNDSDOERFER A. K. 2017. A new alien species in Europe: first record of Austropeplea viridis (Quoy \& Gaimard, 1833) (Mollusca, Gastropoda, Lymnaeidea) in Spain. Journal of Conchology 42: 357370.

TAMURA K. 1992. Estimation of the number of nucleotide substitutions when there are strong transition-transversion and G + C-content biases. Molecular Biology and Evolution 9: 678-687.

Tautz D., ARCtander P., Minelli A., Thomas R. H., VOGLER A. P. 2003. A plea for DNA taxonomy. Trends in Ecology \& Evolution 18: 70-74. https://doi. org/10.1016/S0169-5347(02)00041-1

Thomaz D., Guiller A., Clarke B. 1996. Extreme divergence of mitochondrial DNA within species of pulmonate land snails. Proceedings of Royal Society B: Biological Sciences 263: 363-368. https://doi. org/10.1098/rspb.1996.0056

Thompson J. D., Higgins D. G., GiBson T. J. 1994. CLUSTAL W: improving the sensitivity of progressive multiple sequence alignment through sequence weighting, position specific gap penalties and weight matrix choice. Nucleic Acids Research 22: 4673-4680. https://doi.org/10.1093/nar/22.22.4673

VINARSKI M. V. 2003. The systematic position of Lymnaea vulnerata (Küster, 1862) and L. occulta (Jackiewicz, 1959) (Mollusca: Gastropoda: Lymnaeidae). Zoosystematica Rossica 12: 23-27.

VINARSKI M. V. 2012. The lymnaeid genus Catascopia Meier-Brook et Bargues, 2002 (Mollusca: Gastropoda: Lymnaeidae), its synonymy and species composition. Invertebrate Zoology 9: 91-104. https://doi. org/10.15298/invertzool.09.2.02

ViNARSKi M. V., AKSENOVA O. V., BESPALAYA Y. V., BOLOTOV I. N., Gofarov M. Y., KONDAKOV A. V. 2016 b. Ladislavella tumrokensis: the first molecular evidence of a Nearctic clade of lymnaeid snails inhabiting Eurasia. Systematics and Biodiversity 14: 276-287. https://doi. org/10.1080/14772000.2016.1140244
VinARSKi M. V., Bolotov I. N., SCHNiEBS K., NEKHAEV I. O., HUNDSDOERFER A. K. 2017. Endemics or strangers? The integrative re-appraisal of taxonomy and phylogeny of the Greenland Lymnaeidae (Mollusca: Gastropoda). Comptes Rendus Biologies 340: 541-557. https://doi. org/10.1016/j.crvi.2017.09.005

VINARSKI M. V., GLÖER P. 2008. Taxonomic notes on EuroSiberian freshwater molluscs. 3. Galba occulta Jackiewicz, 1959 is a junior synonym of Limnaea palustris var. terebra Westerlund, 1885. Mollusca 26: 175-185.

VINARSKI M. V., SCHNIEBS K., GLÖER P., HUNDSDOERFER A. K. 2011. The taxonomic status and phylogenetic relationships of the genus Aenigmomphiscola Kruglov and Starobogatov, 1981 (Gastropoda: Pulmonata: Lymnaeidae). Journal of Natural History 45: 20492068. https://doi.org/10.1080/00222933.2011.574800

ViNARSKi M. V., SCHNIEBS K., GlÖER P., NeKHAEV I. O., HunDSDOERFER A. K. 2014. Geography rather than morphology explains the genetic diversity within the Lymnaea stagnalis s. 1. complex (Mollusca, Gastropoda, Pulmonata) in Eurasia. Sequences available online at GenBank https://www.ncbi.nlm.nih.gov/genbank/ (Accessed 21 October 2018)

VINARSKI M. V., SCHNIEBS K., GLÖER P., SON M. O., HUNDSDOERFER A. K. 2016a. The steppe relics: taxonomic study on two lymnaeid species endemic to the former USSR. Archiv für Molluskenkunde 141: 67-85. https:// doi.org/10.1127/arch.moll/1869-0963/141/067-085

WALTER H. J. 1969. Illustrated biomorphology of the "angulata" lake form of the basommatophoran snail Lymnaea catascopium Say. Malacological Review 2: 1-102.

Westerlund C. A. 1885. Fauna der in der Paläarktischen Region lebenden Binenconchylien. Fam. Succineidae, Auriculidae, Limnaeidae, Cyclostomidae und Hydrocenidae. Olsson, Lund.

Received: November 20th, 2017

Revised: November 28th, 2018

Accepted: November 29th, 2018

Published on-line: December 11th, 2018 


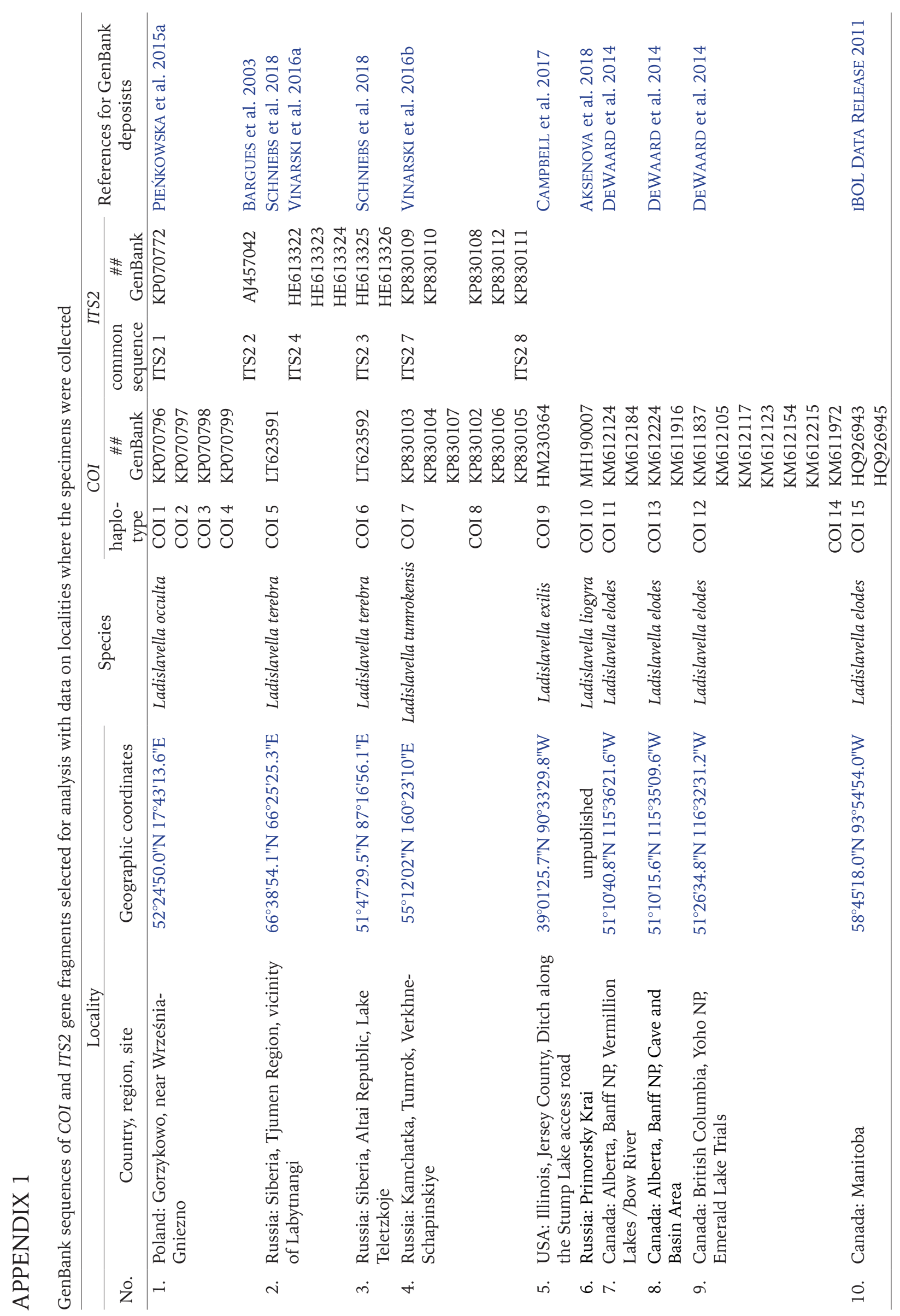




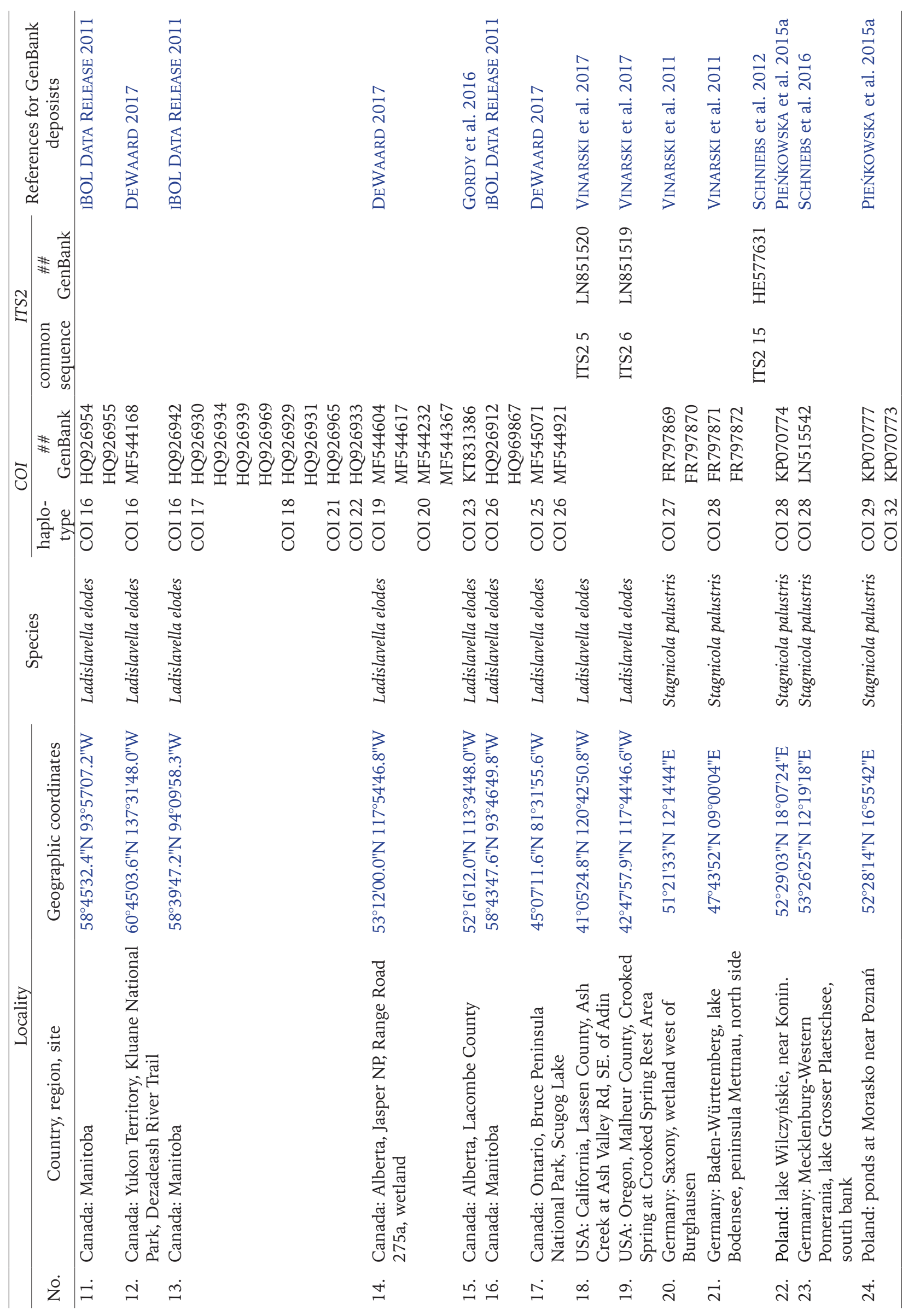




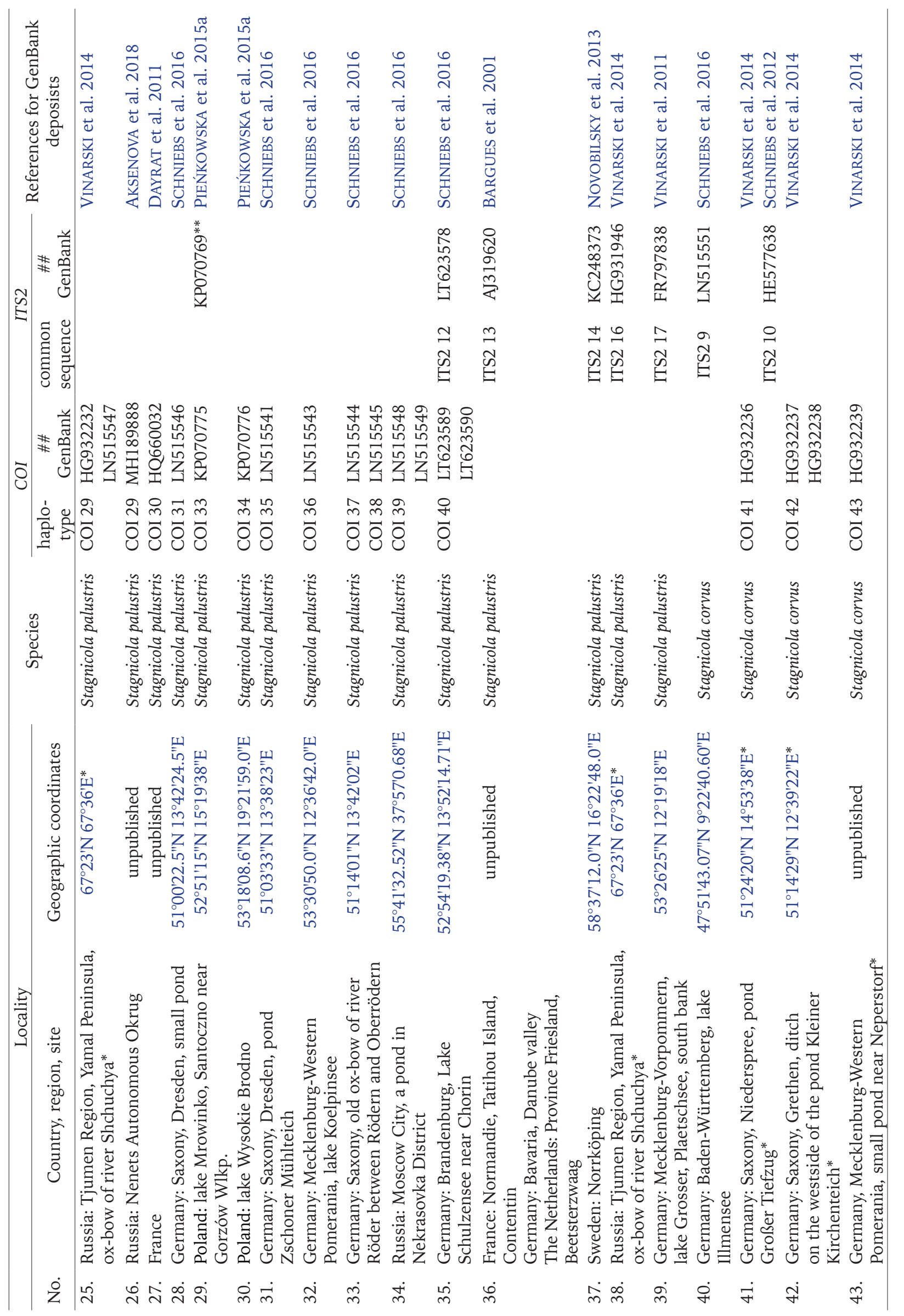




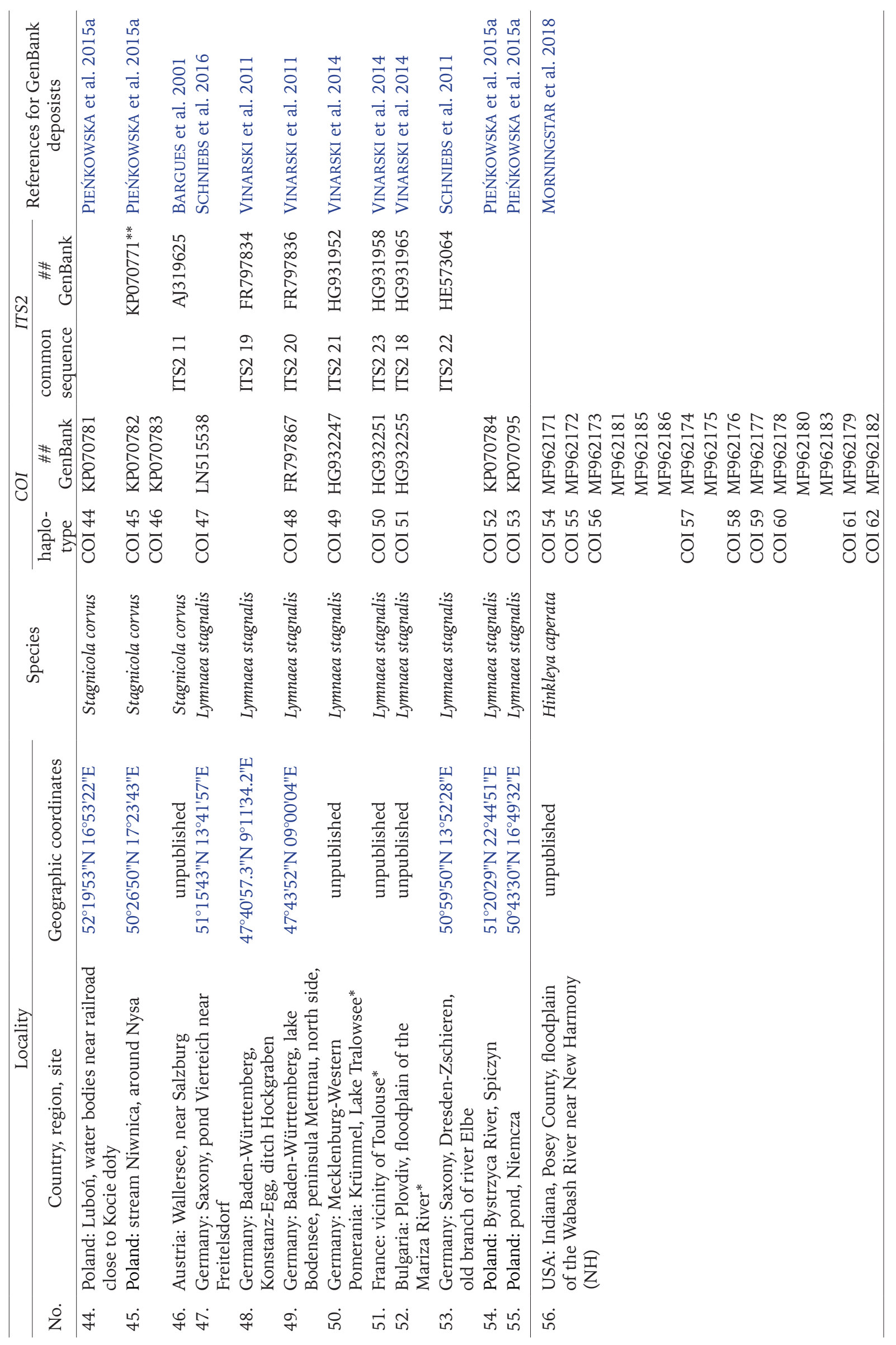




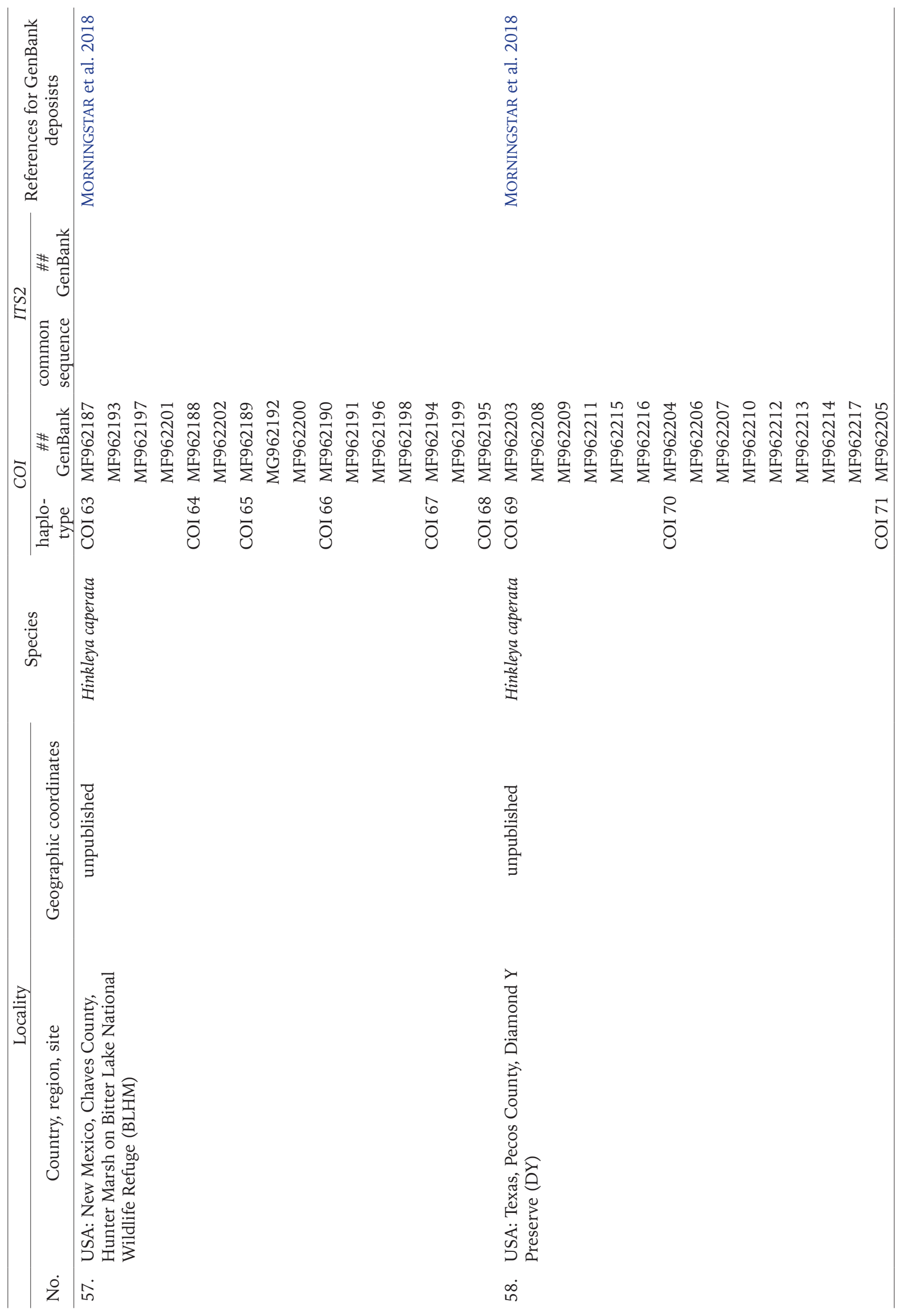




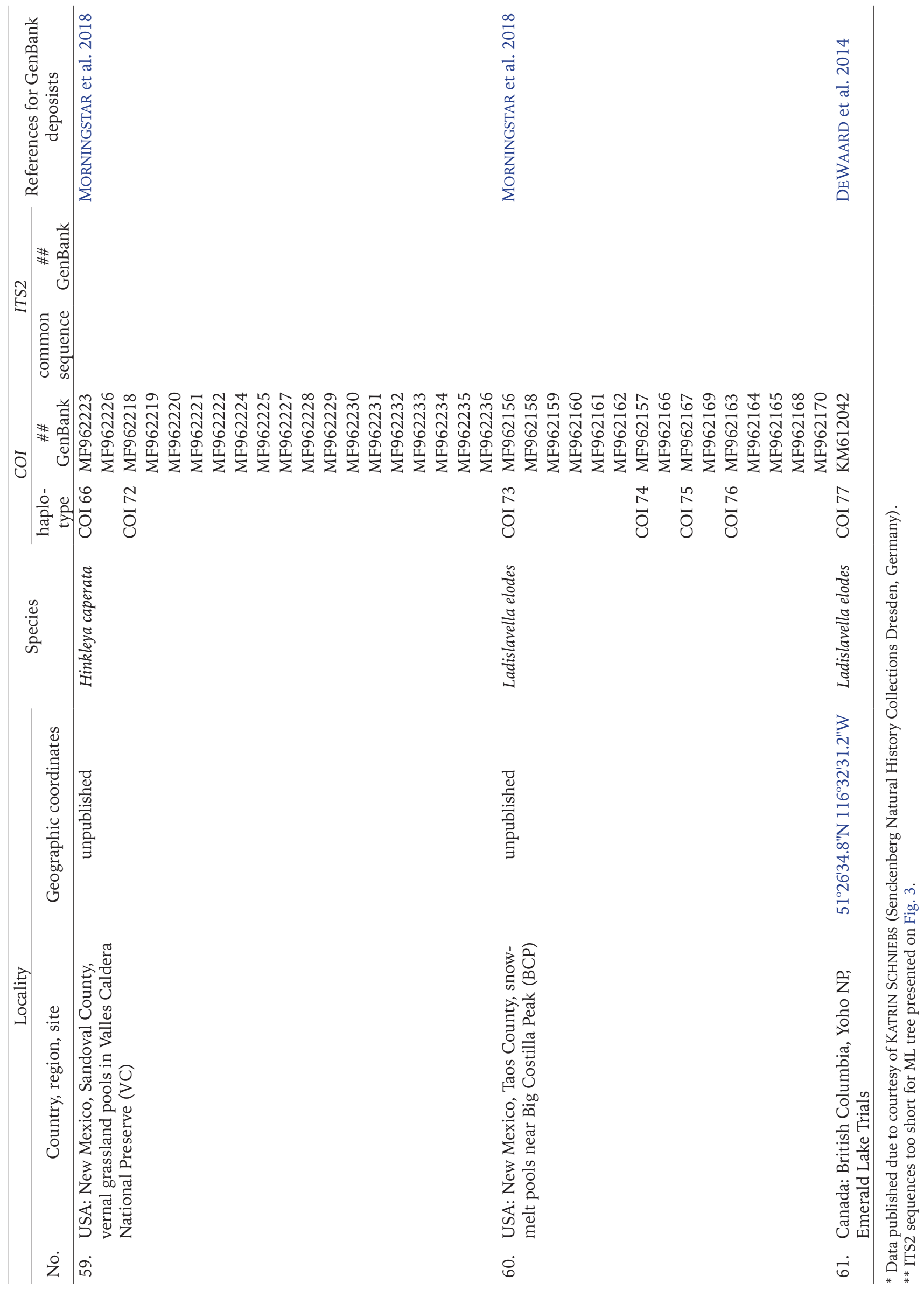

